\title{
KAJIAN NILAI GIZI DAN ORGANOLEPTIK COKELAT MANGROVE DARI BUAH SONNERATIA ALBA
}

\author{
Wintah $^{1^{*}}$, Andhina Putri Heriyanti ${ }^{2}$, Kiswanto $^{3}$ \\ ${ }^{1,3}$ Fakultas Kesehatan Masyarakat, Universitas Teuku Umar \\ ${ }^{2}$ Fakultas Ilmu Pendidikan, IKIP Veteran Semarang \\ Korespondensi:wintah@utu.ac.id
}

\begin{abstract}
Pekalongan has natural resource potential in the form of mangroves, one of which is the type of Sonneratia alba or pedada. Pedada fruit has not been maximally utilized, it is necessary to use pedada as food processing material in the form of mangrove chocolate. The purpose of this activity is (1) Knowing the nutritional value contained in mangrove chocolate. (2) Knowing the hedonic rating value (preference) for mangrove chocolate. Proximate analysis method descriptively by knowing the nutritional value of chocolate mangrove. The measured parameters are protein, vitamin $C$, fat, water, ash and carbohydrates. The brown organoleptic test of mangrove to assess the results of prcessed magrove chocolate through the sensory organs in the form of taste, color, aroma, and texture. The organoleptic test used is the hedonic rating test (preference). The organoleptic test results showed that the preferred mangrove chocolate was P2 (30\%mangrove: $20 \%$ flour). The nutritional value of mangrove chocolate for 100 grams contained $5.56 \%$ protein, vitamin C $0.88 \%$, fat $29.85 \%$, water $10.3 \%$, ash content $0.5 \%$, and carbohydrates $53.7 \%$. Inclusion of nutrient content in mangrove processed products can provide information that in addition to being delicious for consumption, mangrove are good for health because they contain nutrients needed by the body. The results of variance showed that color, taste, aroma, and texture affected the mangrove chocolate.
\end{abstract}

Keywords: Sonneratia alba, Chocolate mangrove, Nutritional value, Hedonic value.

\begin{abstract}
ABSTRAK
Pekalongan mempunyai potensi sumber daya alam berupa buah mangrove salah satunya jenis Sonneratia alba atau buah pedada. Buah pedada belum dimanfaatkan secara maksimal oleh karena itu perlu adanya pemanfaatan buah pedada sebagai bahan olahan makanan berupa cokelat mangrove. Tujuan dari kegiatan ini adalah (1) Mengetahui nilai gizi yang terkandung pada cokelat mangrove. (2) Mengetahui nilai rating hedonik (kesukaan) pada cokelat mangrove. Metode analisis proksimat secara deskriptif dengan mengetahui kandungan gizi cokelat mangrove. Parameter yang diukur yaitu kandungan protein, Vitamin C, lemak, air, abu, dan karbohidrat. Uji organoleptik cokelat mangrove untuk menilai hasil olahan coklat mangrove melalui organ indra berupa rasa, warna, aroma, dan tekstur. Uji organoleptik yang digunakan adalah uji rating hedonik (kesukaan). Hasil uji organoleptik menunjukkan cokelat mangrove yang sangat disukai adalah perlakuan P2 (Mangrove $30 \%$ :Tepung 20\%). Nilai gizi pada cokelat mangrove untuk $100 \mathrm{gr}$ mengandung protein $5,56 \%$, vitamin C $0,88 \%$, lemak $29,85 \%$, air $10,3 \%$, kadar abu $0,5 \%$, dan karbohidrat 53,7\%. Pencantuman kandungan gizi pada produk olahan mangrove dapat memberikan informasi bahwa selain nikmat untuk dikonsumsi, mangrove baik untuk kesehatan karena mengandung gizi yang dibutuhkan oleh tubuh. Hasil sidik ragam menunjukkan bahwa warna, rasa, aroma, dan tekstur berpengaruh terhadap cokelat mangrove.
\end{abstract}

Kata Kunci: Sonneratia alba, Cokelat mangrove, Nilai gizi, Nilai hedonik.

\section{PENDAHULUAN}

Pantai pesisir Pekalongan terdapat hutan magrove yang luasnya lebih dari $50 \mathrm{Ha}$. Hutan mangrove itu telah dijadikan wisata mangrove oleh pemerintah Pekalongan. Spesies pohon mangrove yang berada di pesisir pantai lebih didominasijenis Rhizophora 
$s p$ dan Sonneratia sp (Kiswanto, 2013). Buah pedada (Sonneratia sp) merupakan buah yang bagian dasarnya terbungkus kelopak bunga, berbentuk bola, dan ujung buah tersebut bertangkai. Buah tersebut tidak beracun dan langsung dapat dimakan. Buah pedada memiliki rasa yang asam dan aroma yang khas yang menjadi daya tarik buah tersebut (Santoso et al, 2008).

Sonneratia sp merupakan tumbuhan mangrove yang mempunyai kuantitas buah yang cukup tinggi karena pada saat tidak musim, pohon masih bisa menghasilkan kurang lebih $2 \mathrm{~kg}$ /hari. Buah Sonneratia sp dapat diolah untuk dijadikan berbagai produk olahan makanan dan minuman. Sekarang ini olahan mangrove telah banyak dilakukan berbagai produk olahan yang bervariasi salah satu olahan yang menjadi trens adalah coklat mangrove.

Pekalongan mempunyai potensi sumber daya alam berupa buah mangrove salah satunya jenis Sonneratia alba yang dapat dimanfaatkan sebagai bahan olahan makanan berupa coklat mangrove. Coklat mangrove adalah jenis makanan berbahan baku buah mangrove. Alasan pembuatan coklat dari mangrove dikarenakan mulai anak-anak sampai orang dewasa menyukai makanan coklat. Oleh karena itu, perlu adanya kajian nilai gizi dan organoleptik coklat mangrove.

\section{RUMUSAN MASALAH}

Permasalahan dapat dirumuskan sebagai berikut:

1. Belum adanya kajian nilai gizi pada cokelat mangrove dari buah Sonneratia alba

2. Belum adanya kajian organoleptik pada cokelat mangrove dari buah Sonneratia alba.

\section{TINJAUAN PUSTAKA}

Mangrove berfungsi sebagai penahan abrasi dan penangkap sedimen. Ekosistem mangrove berfungsi sebagai daerah asuhan, mencari makan dan daerah pemijahan. Kayu mangrove dimanfaatkan sebagai kayu bakar dan obat-obatan. Sedangkan buah dapat diolah menjadi beragam makanan (Noor et al., 2006).

Pencantuman kandungan gizi pada produk olahan mangrove dapat memberikan informasi bahwa selain nikmat untuk dikonsumsi, mangrove baik untuk kesehatan karena mengandung gizi yang dibutuhkan oleh tubuh. Buah mangorove yang biasa dikonsumsi oleh masyarakat Indonesia adalah buah Bruguiera, Rhizophora, Acrostichum, Avicennia, dan Sonneratia (Ilham et al.,2011). Spesies Sonneratia merupakan jenis mangrove yang telah banyak dimanfaatkan oleh masyarakat menjadi produk olahan pangan seperti kue, jus, dan selai. Sonneratia memiliki beberapa keunggulan dibandingkan dengan jenis tanaman mangrove lainnya yaitu sifat buahnya tidak beracun dan dapat dimakan secara langsung tanpa diolah terlebih dahulu (Priyono et al., 2010). Sonneratia yang sudah masak mempunyai rasa dan aroma yang khas. Sonneratia juga mengandung serat dan mineral (Jariyah et al., 2014). Ekstrak Sonneratia memiliki aktivitas antioksidan yang kuat (Bunyapraphatsara et al., 2003). Senyawa yang bersifat antioksidan dapat mempengaruhi efikasi antioksidan lain (Boots et al., 2008). Selain antioksidan, Sonneratia juga kaya akan serat dan mineral (Jariyah et al., 2014).

Buah Sonneratia sp telah banyak diolah untuk dijadikan beberapa produk pangan seperti jenang, dodol dan sirup. Buah Sonneratia caseolaris memiliki beberapa keunggulan dibandingkan dengan jenis tanaman mangrove lainnya yaitu sifat buahnya tidak beracun, dapat dimakan langsung. Rasa asam dan aroma yang khas serta tekstur buah yang lembut membuat buah Sonneratia caseolaris cocok diolah menjadi sirup 
(Indra et al., 2007). Terdapat beberapa spesies mangrove yang tumbuh di Indonesia. Buah mangorove yang biasa dikonsumsi oleh masyarakat Indonesia adalah Bruguiera, Rhizophora, Acrostichum, Avicennia, and Sonneratia (Ilham et al., 2011).

\section{METODE PENELITIAN}

Metode penelitian dengan wawancara secaara purposive artinya subyek penelitian sebagai sumber data yang dipilih dengan pertimbangan tertentu (Sugiyono, 2014). Nilai gizi menggunakan analisis proksimat dilakukan laboratorium kimia organik, Fakultas MIPA Universitas Jenderal Soedirman. Uji organoleptik cokelat mangrove untuk menilai hasil olahan coklat mangrove melalui organ indra berupa rasa, warna, aroma, dan tekstur. Uji organoleptik menggunakan rating hedonik (kesukaan) dengan menggunakan skala penilaian 1( sangat tidak suka), 2 (tidak suka), 3 (kurang suka), 4 (suka), dan 5 (sangat suka).

\section{HASIL DAN PEMBAHASAN}

\subsection{Uji Nilai Gizi}

Uji nilai gizi dilakukan pada salah satu perlakuan yang paling disukai oleh panelis yaitu perlakuan P2. Uji komposisi nilai gizi yang terkandung pada cokelat mangrove melalui uji proksimat. Uji proksimat meliputi; protein, vitamin $\mathrm{C}$, lemak, kadar air, kadar abu, dan karbohidrat. (Tabel 1)

Tabel 1.Nilai gizi cokelat mangrove

\begin{tabular}{cll}
\hline No & Nilai Gizi & Hasil (\%) \\
\hline 1 & Protein & 5,56 \\
2 & Vitamin C & 0,88 \\
3 & Lemak & 29,85 \\
4 & Kadar Air & 10,3 \\
5 & Kadar Abu & 0,5 \\
6 & Karbohidrat & 53,7 \\
\hline
\end{tabular}

Kandungan nilai gizi pada suatu bahan makanan merupakan parameter penting bagi konsumen untuk memilih makanan yang akan dikonsumsi. Kandungan nilai gizi cokelat mangrove antara lain;

\subsection{Protein}

Protein merupakan zat gizi yang amat penting bagi tubuh, karena zat ini disamping berfungsi sebagai bahan bakar dalam tubuh juga berfungsi sebagai zat pembangun dan pengatur (Winarno, 2008).

Hasil pengujian kadar protein yang terdapat pada coklat mangrove sebesar $5,56 \% / 100$ gram. Febrianti (2010) menyatakan bahwa kadar protein buah pedada $1,17 \%$. Menurut Satuhu (2004) buah yang paling cocok dimanfaatkan untuk diolah menjadi produk pangan sebaiknya mempunyai kandungan protein lebih besar dari $1 \%$. Dengan demikian kadar protein yang terdapat pada coklat mangrove telah memenuhi syarat. Analisis protein dapat dilakuka dengan penentuan jumlah protein secara empiris. Pengujian yang paling umum dilakukan adalah dengan menentukan jumlah nitrogen $(\mathrm{N})$ yang dikandung suatu bahan. Penentuan protein berdasarkan jumlah nitrogen menunjukkan protein kasar karena selain protein juga terikut senyawa nitrogen lainnya (Indarto, 2009). 


\subsection{Vitamin $C$}

Massot et al. (2010) menyatakan bahwa vitamin $C$ berperan penting dalam mencegah penyakit scurvy yaitu penyakit yang menyebabkan pucat, rasa lelah, dan pendarahan gusi.

Hasil uji kandungan vitamin $\mathrm{C}$ pada buah pedada adalah $0,88 \% / 100 \mathrm{~g}$. Menurut Satuhu (2004) buah yang paling cocok dimanfaatkan untuk diolah menjadi produk pangan sebaiknya mempunyai kandungan vitamin $\mathrm{C}$ lebih besar dari 0,01\%. Dengan demikian kadar vitamin $\mathrm{C}$ yang terkandung dalam buah pedada memenuhi syarat untuk diolah menjadi cokelat mangrove.

\subsection{Lemak}

Lemak merupakan simpanan energi paling utama di dalam tubuh. Lemak larut dalam pelarut nonpolar, seperti etanol, eter, kloroform, dan benzena. Lemak merupakan senyawa kimia yang terdiri atas unsur-unsur karbon, hidrogen, dan oksigen (Almatsier 2004).

Hasil pengujian kadar lemak pada buah pedada diperoleh 29,85\%. Febrianti (2010) menyatakan bahwa kadar lemak buah pedada sebesar 0,89\%. Kadar lemak yang terkandung dalam coklat mangrove sebesar 29,85\% lebih tinggi dari kadar lemak buah pedada. Hal ini disebabkan oleh pembuatan cokat mangrove menggunakan bahan tambahan margarin.

Menurut Satuhu (2004) buah yang paling cocok dimanfaatkan untuk diolah menjadi produk pangan sebaiknya mempunyai kandungan lemak lebih besar dari $0,1 \%$.

\subsection{Kadar Air}

Kadar air adalah perbedaan antara berat bahan sebelum dan sesudah dilakukan pemanasan, persentase kandungan air suatu bahan yang dapat dinyatakan berdasarkan berat basah (wet basis) atau berdasarkan berat kering (dry basis). Air merupakan kandungan penting dalam bahan pangan karena salah satu karakteristik yang sangat penting dalam bahan pangan.. Penurunan kadar air dapat dilakukan dengan beberapa cara yaitu pengeringan, evaporasi konsentrat atau pembekuan. Penentuan kadar air terhadap brownies tersebut menggunakan metode berat kering (dry basis) (Ishak, 2006).

Hasil uji kadar air menunjukkan bahwa kadar air 10,31 \%/100 gr. Cokelat mangrove memiliki kadar air yang rendah. dibandingkan dengan hasilpenelitian Febrianti (2010) yang menyatakan bahwa kadar air buah pedada 79,24\%. Kadar air yang rendah pada cokelat mangrove disebabkan oleh penambahan gula pada saat pembuat coklat mangrove. Ferreira et al. (2004) menyatakan bahwa gula dapat mengikat air secara efisien. Sehingga, penambahan gula pada cokelat mangrove dapt memberikan efek pengawetan.

\subsection{Kadar Abu}

Kadar abu dalam makanan berasal dari zat anorganik sisa pembakaran yang terdiri dari bagan mineral seperti fosfor, kalsium, belerang, sodium dan bahan lainnya (Winarno, 2008).

Kadar abu cokat mangrove sebesar $0,53 \%$, nilai ini lebih rendah jika dibandingkan dengan penelitian Febrianti (2010) yang menyatakan bahwa kadar abu 
buah pedada sebesar 4,35\%. Penurunan kadar abu disebkan oleh pengolahan buah pedada menjadi coklat mangrove. Kmiecik et al. (2000) menyatakan bahwa pemasakan suatu bahan secara signifikan dapat menurunkan kadar abu, fosfor, besi, kalsium, dan magnesium.

\subsection{Karbohidrat}

Manalu (2013) menyatakan bahwa buah pedada mengandung kadar karbohidrat 77,57\%. Febrianti (2010) kadar karbohidrat buah pedada 14, 35\%. Perbedaan kandungan karbohidrat pada buah pedada dipengaruhi oleh jenis kematangan buah pedada. Hal ini sesuai dengan pendapat Sumardjo (2009) yang menyatakan bahwa jumlah nutrisi dalam tanaman berbeda-beda tergantung umur fisiologis, kondisi agronomis, dan lingkungan walaupun tanaman tersebut masih dalam satu varietas yang sama.

Hasil uji karbohidrat coklat mangrove sebesar 53,7\%. Tingginya kadar karbohidrat pada coklat mangrove disebabkan oleh penambahan gula dan tepung. Batista et al. (2011) menyatakan bahwa gula merupakan karbohidrat sederhana. Menurut Satuhu (2004) buah yang paling cocok dimanfaatkan untuk diolah menjadi produk pangan sebaiknya mempunyai kandungan karbohidrat lebih besar dari $1 \%$. Dengan demikian, kadar karbohidrat yang terkandung dalam coklat mangrove memenuhi syarat karena kandungan karbohidrat lebih dari $1 \%$.

\subsection{Uji Organoleptik}

Uji organoleptik adalah uji hedonik (kesukaan) merupakan salah satu uji penerimaan konsumen terhadap suatu produk baru. Uji organoleptik menggunakan 25 panelis yang terlatih sebagai wakil konsumen dan diminta untuk mengungkapkan tanggapannya tentang kesukaan atau ketidaksukaan dengan menggunakan skala penilaian 1( sangat tidak suka), 2 (tidak suka), 3 (kurang suka), 4 (suka), dan 5 (sangat suka) terhadap produk cokelat mangrove. Uji organoleptik meliputi rangking mutu rasa, warna, aroma, dan tekstur.

\subsection{Rating Mutu Rasa}

Rasa adalah sifat organoleptik terpenting pada suatu produk. Rasa pada suatu produk dapat dipengaruhi oleh gula. Sifat rasa yang mempengaruhi cita rasa coklat adalah rasa manis (Wahyudi, 2008).

Hasil uji rangking kesukaan rasa menunjukkan bahwa panelis sangat menyukai rasa cokelat pada perlakuan P2 (Perbandingan buah mangrove 3: tepung 2). Rataan kesukaan rasa pada cokelat mangrove dapat dilihat pada (Tabel 2).

Tabel 2. Hasil uji rangking kesukaan cokelat mangrove

\begin{tabular}{ccclll}
\hline \multirow{2}{*}{ No } & \multirow{2}{*}{ Perlakuan } & \multicolumn{4}{c}{ Parameter } \\
\cline { 3 - 6 } & Rasa & Warna & Aroma & Tekstur \\
\hline 1 & P0 & 2,92 & 2,52 & 2,72 & 2,84 \\
2 & P1 & 3,32 & 3,60 & 3,68 & 3,72 \\
3 & P2 & 4,88 & 4,64 & 4,68 & 4,68 \\
4 & P3 & 4,44 & 4,36 & 4,32 & 4,36 \\
\hline
\end{tabular}

Keterangan:

$\mathrm{P} 0=$ Buah mangrove 0 : Tepung 50

$\mathrm{P} 1=$ Buah mangrove 20: Tepung 30

P2 = Buah Mangrove 30: Tepung 20

P3= Buah Mangrove 40: Tepung 10 
Hasil uji organoleptik parameter rasa pada perbandingan buah mangrove dan tepung terhadap cokelat mangrove pada perlakuan P0 yaitu 2,92 (kurang suka), perlakuan P1 yaitu 4,44 (suka), perlakuan P2 yaitu 4,88 (sangat suka), Perlakuan P3 yaitu 3,32 (kurang suka).

Hasil analisa sidik ragam menunjukkan bahwa rasa pada $\mathrm{F}$ hitung 78,17 lebih besar dari $\mathrm{F}$ tabel 0,05 sehingga rasa berpengaruh terhadap cokelat mangrove. Penambahan buah mangrove pedada dengan berbagai variasi memberi pengaruh yang berbeda nyata terhadap rasa cokelat mangrove yang dihasilkan. Hal ini sesuai dengan Winarno (1996) yang menyatakan bahwa rasa suatu makanan merupakan faktor yang turut menentukan daya terima konsumen. Rasa dipengaruhi oleh beberapa faktor yaitu senyawa kimia, suhu, konsentrasi dan interaksi dengan komponen rasa yang lain.

\subsection{Rating Mutu Warna}

Warna mempunyai peran penting pada komoditas pangan. Penentuan mutu suatu bahan pangan pada umumnya tergantung pada warna, karena warna tampil terlebih dahulu (Winarno, 2008). Warna pada cokelat mangrove yang dihasilkan dapat dipengaruhi oleh bahan tambahan.

Hasil uji organoleptik parameter warna pada perbandingan buah mangrove dan tepung terhadap cokleat mangrove pada perlakuan P0 yaitu 2,52 (tidak suka), perlakuan P1 yaitu 4,36 (suka), perlakuan P2 yaitu 4,64 (sangat suka), Perlakuan P3 yaitu 3,6 (agak suka).

Hasil analisa sidik ragam menunjukkan bahwa warna pada $\mathrm{F}$ hitung 72,03 lebih besar dari $\mathrm{F}$ tabel 0,05 sehingga warna berpengaruh terhadap cokelat mangrove. Cokelat mangrove berwarna cokelat agak gelap terbentuk karena pada buah mangrove mengandung pigmen buah berwarna putih kecokelatan. Hal ini sesuai dengan Winarno (1996), yang menyatakan bahwa penyebab suatu bahan makanan berwarna adalah salah satunya karena adanya pigmen yang dikandung oleh bahan makanan tersebut. Warna pigmen buah umumnya putih cokelat, dan biasanya dijumpai pada sayuran dan buah-buahan.

\subsection{Rating Mutu Aroma}

Aroma menjadi daya tarik dalam pengolahan produk makanan. Aroma yang disebarkan oleh makanan merupakan daya tarik yang sangat kuat dan mampu merangsang indera penciuman penerima sehingga membangkitkan selera.

Menurut Satuhu (2004) bahwa buah pedadaatau Sonneratia caseolaris memiliki kandungan zat-zat volatil yang menimbulkan aroma segar pada buah sehingga cokelat mangrove yang dibuat dari buah akan memiliki aroma sesuai dengan buah aslinya.

Hasil uji organoleptik parameter aroma pada perbandingan buah mangrove pedada dan tepung terhadap coklat mangrove pada perlakuan P0 yaitu 2,72 (kurang suka), perlakuan P1 yaitu 4,32 (suka), perlakuan P2 yaitu 4,68 (sangat suka), Perlakuan P3 yaitu 3,68 (suka).

Hasil analisa sidik ragam menunjukkan bahwa aroma pada $\mathrm{F}$ hitung 64,78 lebih besar dari $\mathrm{F}$ tabel 0,05 sehingga aroma berpengaruh terhadap cokelat mangrove. Hal ini dipengaruhi oleh penambahan buah mangrove pedada yang memiliki aroma khas, semakin tinggi konsentrasi penambahan buah mangrove pedada maka aroma 
yang dihasilkan semakin kuat. Winarno (1996) menyatakan bahwa penerimaan indera penciuman akan berkurang oleh adanya senyawa-senyawa tertentu seperti misalnya formaldehida dan kelelahan daya penciuman terhadap bau dapat terjadi dengan cepat.

\subsection{Rangking Mutu Tekstur}

Tekstur digunakan untuk menyatakan bentuk fisik produk. Tekstur juga berpengaruh terhadap daya tarik terhadap seseorang. Rampengan (1985) menyatakah bahwa salah satu cara penentuan tekstur suatu bahan adalah dengan memberikan beban terhadap bahan misalnya dengan pemeriksaan bekas jari.

Hasil uji organoleptik parameter tekstur pada perbandingan buah mangrove pedada dan tepung terhadap cokelat mangrove pada perlakuan P0 yaitu 2,84 (kurang suka), perlakuan P1 yaitu 4,36 (suka), perlakuan P2 yaitu 4,68 (sangat suka), Perlakuan P3 yaitu 3,72 (suka).

Hasil analisa sidik ragam menunjukkan bahwa tekstur pada $\mathrm{F}$ hitung 57,27 lebih besar dari F tabel 0,05 sehingga tekstur berpengaruh terhadap cokelat mangrove. Hal ini dipengaruhi oleh penambahan buah mangrove pedada, dimana buah mangrove pedada memiliki tekstur yang berserat, sehingga semakin tinggi konsentrasi penambahan buah mangrove pedada pada pembuatan cokelat mangrove maka semakin tidak disukai oleh panelis.

Hasil uji organoleptik secara keseluruhan panelis sangant menyukai perlakuan P2 yaitu perbandingan buah mangrove 30: tepung 20. Uji nilai gizi dilakukan pada salah satu perlakuan yang paling disukai oleh panelis yaitu perlakuan P2.

\section{KESIMPULAN DAN SARAN}

\subsection{Kesimpulan}

1. Kandungan gizi cokelat mangrove untuk 100 gr mengandung protein 5,56\%, vitamin C 0,88\%, lemak 29,85\%, air 10,3\%, kadar abu 0,5\%,dan karbohidrat $53,7 \%$.

2. Hasil uji organoleptik, sampel yang sangat disukai adalah sampel P2 (Mangrove 30\%:Tepung 20\%:Coklat 20\%:Gula 20\%:Margarin 10\%).

3. Hasil sidik ragam menunjukkan bahwa warna, rasa, aroma, dan tekstur berpengaruh terhadap cokelat mangrove.

\subsection{Saran}

1. Perlu adanya penelitian lanjutan mengenai kemasan dan daya simpan cokelat buah mangrove.

2. Perlu adanya program pendampingan lebih lanjut agar pengembangan usaha berbasis kearifan lokal dapat berjalan lancar.

3. Perlu sinergisitas unsur pentahelix yaitu peran pemerintah, akademisi, asosiasi, komunitas, dan media. 


\section{DAFTAR PUSTAKA}

Almatsier, S. 2004. Prinsip dasar Ilmu Gizi. Gramedia. Jakarta.

Batista, C., Barros, L., Carvalho, A.M., Ferreira, I.C.F.R. 2011. Nutritional and nutraceutical potential of rape (Brassica napus L. var. napus) and "tronchuda" cabbage (Brassica oleraceae L. var. costata) inflorescences. Food and Chemical Toxicology 49(6):1208-1214.

Boots, Agnes W., Haenan, Guido R.M.M., Bast, and Aalt. 2008. Health Effects of Quercetin: from Antioxidant to Nutraceutical. European Journal of Pharmacology. 585: 325-337.

Bunyapraphatsara, Nuntavan, Jutiviboonsuk, Aranya, Somlek, Prapinsara, Therathanathom, Wiroj, Aksomkaew, Sanit, H.S.Fong Harry, M. Pezzuto, John,and K.Jerry. 2003. Pharmacological Studies of Plants in The Mangrove Forest. Thai Journal of Phytopharmacy. 10 (2): 1-12.

Febrianti, F. 2010. Kandungan total Fenol, Komponen Bioaktif dan Aktivitas Antioksidan Buah Pedada (Sonneratia Caseolaris). Fakultas Perikanan dan Ilmu Kelautan IPB. Bogor.

Ferreira, I., Pestana, N., Alves, M.R., Mota, F.J.R., Reu, C., Cunha, S., Oliveira, M. 2004. Quince Jam Quality: Microbiological, physicochemical, and Sensory evaluation. Journal Food Control. 15 (4): 291-295.

Indarto, C. 2009. Petunjuk Praktikum Analisis Pangan. Universitas Trunojoyo. Madura.

Indra, R.., Nofita, Y., dan Wahyu, A. 2007. Identifikasi ekosistem mangrove di Surabaya. Penelitian. Universitas Airlangga. Surabaya.

Ishak, J., Abdurachman, A., dan Umi, H. 2006. Sifat Fisik Tanah dan Metode Analisisnya. Balai Besar Penelitian dan Pengembangan Sumberdaya Lahan Pertanian. Badan Penelitian dan Pengembangan Pertanian. Departemen Pertanian Bogor.

Ilham, M., Wibisono, Iwan T. C., Suryadiputra, I Nyoman, N. 2011. Stateof the Art Information on Mangrove Ecosystem in Indonesia. Wetlands International Indonesian Programme. Bogor.

Jariyah, Widjanarko, S.B., Yunianta, Estiasih, T., and Sopade P.A. 20014. Pasting Propeties Mixtures of Mangrove Fruit Flour (Sonneratia Caseolaris) and Starches. International Food Research Journal. 21 (6): 2161-2167.

Kiswanto. 2013. Pengaruh Stok Karbon Tersimpan Pada Hutan Mangrove Buatan di Area Bekas Tsunami di Aceh Barat Selatan. Jurnal perikanan dan kelautan. 1 (1): 25-28.

Kmiecik,W., Lisiewska, Z., Jaworska, G. 2000. Content of ash component in the fresh and preserved broad bean (Vicia faba $v$ major). Journal of Food Composition and Analysis 13(6):905-914.

Massot C, Genard M, Stevens R, Gautier H. 2010. Fluctuations in sugar content are not determinant in explaining variations in vitamin $\mathrm{C}$ in tomato fruit. Plant Physiology and Biochemistry. 48(9):751-757.

Manalu, R.D.E.E., Ella, S., Fifi, R., Dan Nia, K. 2013. Kandungan Zat Gizi Makro dan Vitamin Produk Buah Pedada (Sonneratia Caseolaris). Jurnal Penelitian Gizi dan Makanan. 36 (2): 135-140.

Noor, Y.R., M. Khazali, dan N.N. Suryadiputra. 2006. Panduan Pengenalan Mangrove di Indonesia. Wetlands International Indonesia Programe, Bogor. 
Priyono, A., Diah, I., Mohson, L.S., dan Tengku L. 2010. Beragam Produk Olahan Berbahan Dasar Mangrove. KeSemat, Semarang.

Rampengan, V.J. Pontoh, D.T Sambel. 1985. Dasar-Dasar Pengawasan Mutu Pangan. Badan Kerjasama Perguruan Tinggi Negeri Indonesia Bagian Timur, Makassar.

Santoso, N., Kusmana, C., Sudarma.D., dan Sukmandi, R. 2008. Ekologi tumbuhan pidada (Sonneratia caseolaris L) pada kawasan Muara Angke propinsi daerah khusus ibu kota Jakarta. Jurnal KKMN.

Satuhu S. 2004. Penanganan dan Pengolahan Buah. Penebar Swadaya. Jakarta.

Sumardjo, D. 2009. Pengantar Kimia: Buku Panduan Kuliah Mahasiswa Kedokteran dan Program Strata 1 Fakultas Bioeksakta. Penerbit Buku Kedokteran EGC. Jakarta.

Winarno, F.G. 2008. Kimia Pangan dan Gizi. M-Brioo Press. Bogor.

Winarno, F.G. 1996. Kimia Pangan dan Gizi. Gramedia Pustaka Utama. Jakarta.

Wahyudi, T., Pangabean, T.R., dan Pujiyanto. 2008. Panduan Lengkap Kakao: Manajemen agribisnis dari Hulu hingga Hiir. Penebar Swadaya. Jakarta. 